\title{
Cholesteryl Lignocerate Hydrolysis in Adrenoleukodystrophy
}

\author{
VIRGINIA V. MICHELS ${ }^{(13)}$ AND ARTHUR L. BEAUDET \\ Howard Hughes Medical Institute, Departments of Pediatrics and Cell Biology, Baylor College of Medicine, Houston, \\ Texas USA
}

\section{Summary}

Because cholesteryl esters with very long chain fatty acids accumulate in Schilder adrenoleukodystrophy, the ability of extracts of such fibroblasts to hydrolyze $\left[{ }^{14} \mathrm{C}\right]$ cholesteryl lignocerate was examined. Hydrolytic activity was detected at $\mathbf{p H} 3.0$, and this activity was impaired by sulfhydryl inactivating agents. Cholesteryl lignocerate hydrolysis was deficient in cells from patients with cholesteryl ester storage disease or Wolman disease due to acid lipase deficiency, but was in the control range for adrenoleukodystrophy fibroblasts. This suggests that cholesteryl lignocerate hydrolysis can be carried out by acid lipase.

\section{Speculation}

Deficiency of a specific lysosomal lipase is probably not the genetic defect in Schilder adrenoleukodystrophy. A defect in long chain fatty acid metabolism may be more likely.

Schilder adrenoleukodystrophy is an X-linked recessive disorder characterized by progressive mental deterioration and adrenal insufficiency (1). The basic defect is unknown. Accumulation of very long chain saturated fatty acids (23:0 to $30: 0)$ in cholesteryl esters, gangliosides and possibly cerebrosides occurs in brain and adrenal gland $(2,3)$. There are conflicting reports as to whether or not cholesterol accumulates in cultured skin fibroblasts $(4,5)$. Recently, increased content of hexacosanoic acid (26:0) was demonstrated in total lipids and in sphingomyelin fatty acids in fibroblasts from affected individuals (6), indicating that the disease is probably expressed in tissue culture. It has been suggested that the defect in adrenoleukodystrophy is the deficiency of a specific acid esterase isozyme responsible for hydrolysis of very long chain fatty acid esters (7). The increase in long chain fatty acids in complex lipids argues somewhat against a specific acid esterase defect. The authors investigated the ability of extracts of cultured skin fibroblasts from five patients with adrenoleukodystrophy to hydrolyze $\left[{ }^{14} \mathrm{C}\right]$ cholesteryl lignocerate $(\mathrm{CL})$, cholesteryl $\left[{ }^{14} \mathrm{C}\right]-$ oleate $(\mathrm{CO})$, and glycerol $\left[{ }^{14} \mathrm{C}\right]$ trioleate $(\mathrm{GT})$. Activity was also measured in extracts from cholesteryl ester storage disease and Wolman disease fibroblasts, in which lysosomal acid lipase (EC 3.1.1.13) is known to be deficient.

\section{MATERIALS AND METHODS}

Cholesteryl $\left[1-{ }^{14} \mathrm{C}\right]$ oleate $(16.4) \mathrm{mCi} / \mathrm{mmole}$ and glycerol $\left[1-{ }^{14} \mathrm{C}\right]$-trioleate $(55 \mathrm{mCi} / \mathrm{mmole})$ were obtained from Amersham (Arlington Heights, IL.), and $\left[4-{ }^{14} \mathrm{C}\right]$ cholesteryl lignocerate (54 $\mathrm{mCi} / \mathrm{mmole}$ ) was obtained from New England Nuclear (Boston, MA). Radioactive substrate and eggyolk lysolecithin (Sigma, St. Louis, MO) were mixed and dried under nitrogen followed by lyophilization overnight. A solution of $0.1 \mathrm{M}$ sodium chloride, $0.02 \%$ sodium azide and $0.01 \mathrm{M}$ Tris- $\mathrm{HCl}(\mathrm{pH} 7.4)$ was added to yield a final concentration of $0.18 \mathrm{mM}$ radioactive substrate and $12.1 \mathrm{mM}$ lysolecithin. The preparation was sonicated with a
Branson W 185 sonifier at 80 watts for $10 \mathrm{~min}$ in 1 -min intervals at $50^{\circ} \mathrm{C}$, then centrifuged at $101,000 \mathrm{~g}$ for $40 \mathrm{~min}$ at $12^{\circ} \mathrm{C}$ and the pellet discarded. In the case of CL, only $29 \%$ of the substrate was recovered in the supernatant. Substrates were stored under nitrogen at $4^{\circ} \mathrm{C}$.

Enzyme extracts were prepared from skin fibroblasts grown as previously described (8). Cell lines with GM designation were obtained from the Human Mutant Cell Repository (Camden, NJ). Line R.L. (\#1088) was obtained from Dr. A. Milunsky. Adrenoleukodystrophy lines A.B., K.S. and R.Z. were obtained from Dr. J. S. O'Brien and cell line K.W. was obtained from Dr. R. R. Howell. Control skin fibroblasts were from nondisease individuals. Cells from single $150 \mathrm{~mm}$ dishes were harvested by scraping in $0.9 \%$ sodium chloride, centrifuged at $1,000 \mathrm{~g}$ for $10 \mathrm{~min}$, decanted, and stored at $-70^{\circ} \mathrm{C}$. Extracts for the $\mathrm{CL}$ and $\mathrm{GT}$ assays were prepared by sonication at 30 watts three times for $5 \mathrm{sec}$ in $1 \mathrm{ml}$ of water followed by centrifugation at $1000 \mathrm{~g}$ for $10 \mathrm{~min}$ at $25^{\circ} \mathrm{C}$. Extracts for the $\mathrm{CO}$ assays were prepared by sonication in $0.6 \mathrm{ml}$ of $0.1 \%$ Triton X-100, $0.25 \%$ sodium cholate, and $50 \mathrm{mM}$ sodium chloride followed by similar centrifugation. Protein determinations were by the method of Lowry et al. (9).

Reaction mixtures for CL hydrolysis were incubated for $3 \mathrm{hr}$ or as indicated at $37^{\circ} \mathrm{C}$ in a total volume of $0.05 \mathrm{ml}$ with following final concentrations: $25-50 \mathrm{mM}$ of sodium citrate-phosphate buffer ( $\mathrm{pH} 3.0$ ), $0.125 \%$ cholic acid, $1 \mathrm{mM}$ dithiothreitol, $10.5 \mathrm{uM}$ $\left[{ }^{14} \mathrm{C}\right]$ cholesteryl lignocerate, $1.5 \mathrm{mg} / \mathrm{ml}$ bovine serum albumin, and $0.2-1.0 \mathrm{mg} / \mathrm{ml}$ extract protein. The reaction was stopped by placing on ice and $30 \mathrm{ul}$ of reaction mixture was spotted on a Silica Gel 60 (Merck) precoated plastic thin-layer chromatography plate preheated at $110^{\circ} \mathrm{C}$ for $30 \mathrm{~min}$. The plate was developed to $5 \mathrm{~cm}$ in chloroform/methanol/water (75:25:4), dried, and redeveloped to $15 \mathrm{~cm}$ in petroleum ether/diethyl ether/ acetic acid $(70: 30: 2)$. The plate was exposed to Kodak XR5 film overnight for autoradiography. Spots representing CL and cholesterol were cut from the plate and counted in $1.5 \mathrm{ml}$ Liquifluor (New England Nuclear) scintillation counting fluid.

Reaction mixtures for $\mathrm{CO}$ and GT hydrolysis were incubated for $30 \mathrm{~min}$ at $37^{\circ} \mathrm{C}$ with the following final concentrations; $0.05 \%$ Triton X-100, $0.125 \%$ sodium cholate, $25 \mathrm{mM}$ sodium chloride, $1.0 \mathrm{mM}$ EDTA, $5.0 \mathrm{mM} \beta$-mercaptoethanol, $25-50 \mathrm{mM}$ of sodium citrate-phosphate buffer ( $\mathrm{pH} 3.0), 36 \mathrm{uM}$ glycerol $\left[{ }^{14} \mathrm{C}\right]$ -oleate, or $36 \mathrm{uM}$ cholesteryl $\left[{ }^{14} \mathrm{C}\right]$ oleate, $1.5 \mathrm{mg} / \mathrm{ml}$ bovine serum albumin, and $0.2-1.0 \mathrm{mg} / \mathrm{ml}$ of extract protein. Hydrolysis was quantitated by the method of Brecher et al. (10) with two modifications: $0.05 \mathrm{M}$ sodium acetate $\mathrm{pH} 4.5$ was added to bring the total volume to $0.30 \mathrm{ml}$, and $0.5 \mathrm{ml}$ of the upper phase was added to $2.0 \mathrm{ml}$ Aquasol-2 (New England Nuclear) scintillation fluid to determine radioactivity.

Because substrate saturation cannot be documented readily as for substrates in aqueous solution, the time for reaction and the enzyme concentration were adjusted to result in a maximum of $10 \%$ hydrolysis; that is $10 \%$ release of radioactivity from cholesteryl esters and 3.3\% release of radioactivity from triglyceride. Ellman reagent, 5,5'-dithiobis-(2-nitrobenzoic acid), (Sigma) was dissolved in $0.05 \mathrm{M}$ Tris-chloride ( $\mathrm{pH} 7.9$ ) but was added directly to enzyme 
reactions without preincubation so that inactivation occurred at the lower reaction $\mathrm{pH}$.

\section{RESULTS}

Using $\left[{ }^{14} \mathrm{C}\right]$ cholesteryl lignocerate substrate, $\left[{ }^{14} \mathrm{C}\right]$ cholesterol produced was separated by thin layer chromatography and quantitated by scintillation counting. Activity was detected in extracts of cultured skin fibroblasts and was shown to be dependent upon time and addition of enzyme (Table 1). Activity was eliminated by the sulfhydryl inactivating Ellman reagent. Reactions were carried out at $\mathrm{pH} 3.0$ since this yielded the highest activity over the $\mathrm{pH}$ range tested (Fig. 1). Activity was affected significantly by a variety of detergents which presumably would affect the physical state of the substrate. Because the substrate was prepared in lysolecithin, the effect of that phospholipid was not examined but activity was markedly stimulated by the addition of cholic acid.

Hydrolysis of $\left[{ }^{14} \mathrm{C}\right]$ cholesteryl lignocerate occurred at a near linear rate up to $4 \mathrm{hr}$ of incubation and up to $20 \mathrm{ug}$ of extract protein per $50 \mathrm{ul}$ reaction as shown in Figures $2 \mathrm{~A}$ and $2 \mathrm{~B}$. This assay method was applied to extracts from control, adrenoleukodystrophy, cholesteryl ester storage disease (CESD) and Wolman fibroblasts. As shown in Table 2, the activity in adrenoleukodystrophy fibroblasts was not significantly different from the normal range. CL hydrolysis activity was markedly impaired in the acid lipase deficient cells from CESD and Wolman patients. The

Table 1. Characteristics of cholesteryl lignocerate hydrolysis by cultured skin fibroblast extracts ${ }^{1}$

\begin{tabular}{lc}
\hline \multicolumn{1}{c}{ Condition } & $\begin{array}{c}\text { pmole }\left[{ }^{14} \mathrm{C}\right] \\
\text { Cholesterol produced }\end{array}$ \\
\hline Experiment 1 & 11.6 \\
$\quad$ Complete & 1.14 \\
Minus Enzyme & 0.913 \\
0 time & 8.27 \\
Minus dithiothreitol & \\
Minus dithiothreitol, plus & 0.110 \\
$\quad$ m m Ellman reagent & \\
Minus dithiothreitol, plus & 9.26 \\
$\quad$ Ellman buffer & \\
$\quad$ Experiment 2 & 13.5 \\
Complete & 5.25 \\
Minus cholic acid & 1.35 \\
Minus enzyme &
\end{tabular}

${ }^{1}$ Assay mixtures were incubated for $180 \mathrm{~min}$ using $14.7 \mu \mathrm{g}$ of control extract protein for experiment 1 and for $105 \mathrm{~min}$ using $29.1 \mu \mathrm{g}$ of control extract protein for experiment 2 .

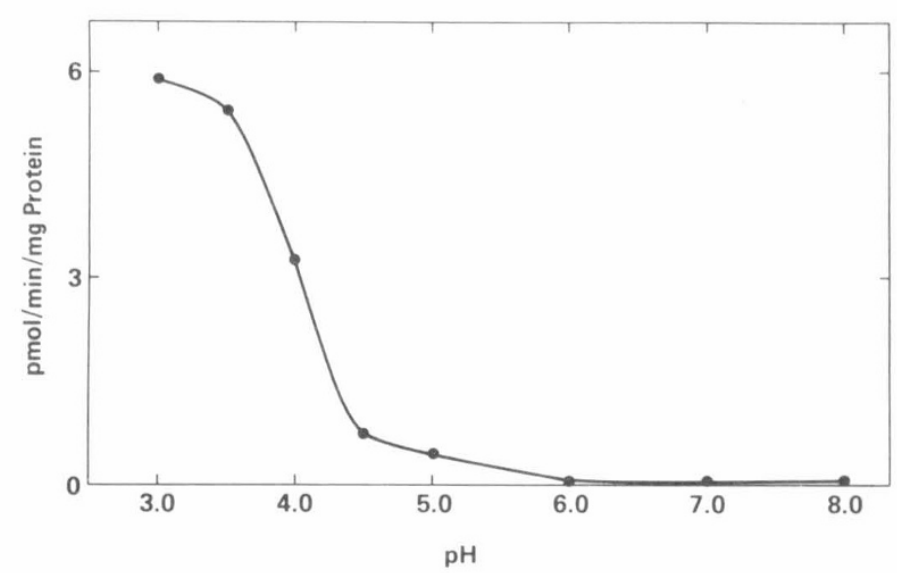

Fig. 1. Dependence on $\mathrm{pH}$ for $\left[{ }^{14} \mathrm{C}\right]$ cholesteryl lignocerate hydrolysis. Reactions were incubated $3 \mathrm{hr}$ with $10 \mu \mathrm{g}$ of protein from a control extract as described in Materials and Methods.

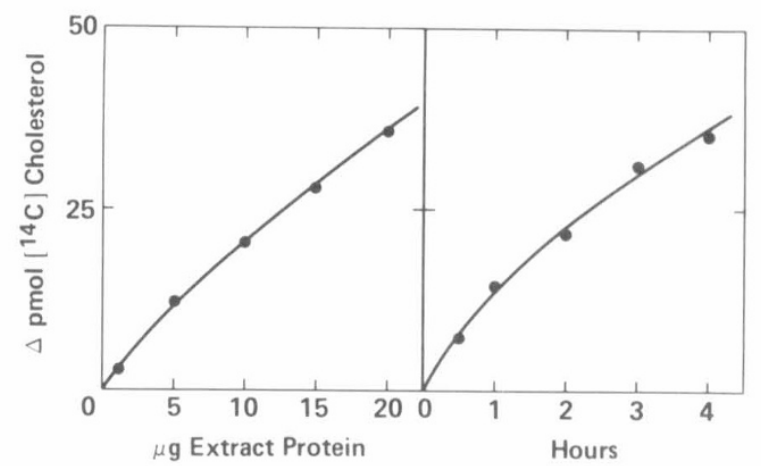

Fig. 2. Enzyme and time concentration curves for $\left[{ }^{14} \mathrm{C}\right]$ cholesteryl lignocerate hydrolysis. Reactions were incubated $3 \mathrm{hr}$ in panel $A$ (left side) and contained $10 \mu \mathrm{g}$ of extract protein in panel $B$ (right side).

Table 2. Lysosomal lipase activity of normal and disease fibroblasts

$\mathrm{pmole}$ hydrolyzed $/ \mathrm{min} / \mathrm{mg}$ protein

Cell line

\begin{tabular}{|c|c|c|}
\hline $\begin{array}{l}{\left[{ }^{14} \mathrm{C}\right]-} \\
\text { olesteryl } \\
\text { nocerate }\end{array}$ & $\begin{array}{c}\text { cholesteryl } \\
{\left[{ }^{14} \mathrm{C}\right]-} \\
\text { oleate }\end{array}$ & $\begin{array}{c}\text { glycerol } \\
{\left[{ }^{14} \mathrm{C}\right]-} \\
\text { trioleate }\end{array}$ \\
\hline
\end{tabular}

Schilder

adrenoleukodystrophy

\begin{tabular}{lccc} 
R.L. \#1088 & 1.98 & 21.2 & 56.1 \\
M.O., GM 623 & 3.10 & 44.2 & 91.1 \\
A.B. & 3.13 & 89.5 & 201.8 \\
K.S. & 4.30 & 60.5 & 247.5 \\
R.Z. & 4.50 & 71.7 & 144.9 \\
$\begin{array}{l}\text { Cholesteryl ester } \\
\text { storage disease }\end{array}$ & & & \\
J.R., GM 863 & 0 & 0.299 & 0.260 \\
K.W. & 0 & 0.634 & 1.32 \\
$\begin{array}{l}\text { Wolman disease } \\
\text { H.W., GM 1606 }\end{array}$ & 0 & 0.621 & 1.35 \\
Fetus A, GM 2211 & 0 & 2.12 & 2.05 \\
Controls (6) & & & \\
$\quad$ Mean & & 81.8 & 139.6 \\
Range & 4.26 & $49.6-120.0$ & $93.3-182.4$ \\
$\quad$ & $2.56-9.04$ & & \\
\hline
\end{tabular}

relative acid lipase activity was evaluated with cholesteryl oleate and glycerol trioleate demonstrating essentially normal activity in adrenoleukodystrophy fibroblasts and deficiency in CESD and Wolman fibroblasts as expected (Table 2).

\section{DISCUSSION}

The basic metabolic defect in X-linked adrenoleukodystrophy remains unknown. The progressive nature of the disorder and the presence of curvilinear inclusions on electron microscopic examination of brain and adrenal tissue (1) might support the possibility that this is a lysosomal storage disease. Biochemical analyses have not demonstrated marked or consistent abnormalities of the quantities of lipid in brain or adrenal gland, although alterations must be interpreted within the framework of nonspecific changes of demyelination. A consistent increase in the fraction of cholesteryl esters containing very long chain fatty acids now seems documented $(2,3)$. This increase in very long chain fatty acids appears to involve gangliosides, and possibly galactosylceramide and sphingomyelin. Similarly, increased very long chain fatty acids were detected in the total lipid and sphingomyelin fractions of cultured skin fibroblasts (6). These data have been interpreted to support a defect in fatty acid or cholesteryl ester metabolism possibly outside the lysosome. Potential enzyme defects would include a specific acyl CoA ligase, carnitine acyl CoA transferase or subsequent steps in the $\beta$-oxidation pathway, the enzymatic steps of the $\alpha$-oxidation pathway, or some cholesteryl ester transfer 
reaction. Deficiency of the ketothioesterase activity of fatty acid synthetase might result in increased synthesis of very long chain saturated fatty acids. Study of adrenoleukodystrophy could result also in the definition of a new metabolic pathway as so often happens. At this time, it is not clear why cerebral white matter and the adrenal gland are the major sites of clinical involvement and what clue this might represent in the pathogenesis.

These data do not demonstrate a lysosomal lipase deficiency as the basis for adrenoleukodystrophy. This is in agreement with the report of Ogino et al. (11) of normal cholesteryl ester hydrolase activity in gray matter brain tissue from patients with adrenoleukodystrophy, although the activity in white matter with the substrate cholesteryl lignocerate was too low for reliable assays. The possibility of a lysosomal lipase deficiency may not be absolutely eliminated, because in vitro conditions, particularly related to detergents and lipid substrates, could give misleading results. If CESD and Wolman disease represented a generalized lysosomal lipase deficiency, including deficiency of some lipase not detected under these in vitro conditions, leukodystrophy and adrenal insufficiency might be expected in these disorders, but this is not the case. At this point, the evidence is against the possibility of a specific lysosomal lipase deficiency as the basis of X-linked adrenoleukodystrophy.

\section{REFERENCES AND NOTES}

1. Schaumburg, H. H., Powers, J. M., Raine, C. S., Suzuiki, K., and Richardson, E. P.: Adrenoleukodystrophy: a clinical and pathological study of 17 cases. Arch.
Neurol., 32: 577 (1975).

2. Igarashi, M., Schaumburg, H. H., Powers, J., Kishimoto, Y., Kolodny E., and Suzuki, K.: Fatty acid abnormality in adrenoleukodystrophy. J. Neurochem., 26: 851 (1976).

3. Menkes, J. H., and Corbo, L. M.: Adrenoleukodystrophy: accumulation of cholesterol esters with very long chain fatty acids. Neurology, 27: 928 (1977).

4. Yavin, E., Milunsky, A., DeLong, G. R., Nash, A. H., and Kolodny, E. H.: Cholesterol metabolism in cultured fibroblasts in adrenoleukodystrophy. Pediatr. Res., 10: 540 (1976).

5. Burton, B. K., and Nadler, H. L.: Schilder's disease: abnormal cholesterol retention and accumulation in cultivated fibroblasts. Pediatr. Res., 8: 170 (1974).

6. Kawamura, N., Moser, A. B., Moser, H. W., Ogino, T., Suzuki, K., Schaumburg, H., Milunsky, A., Murphy, J., and Kishimoto, Y.: High concentration of hexacosanoate in cultured skin fibroblast lipids from adrenoleukodystrophy patients. Biochem. Biophys. Res. Commun., 82: 114 (1978).

7. O'Brien, J. S.: Adrenoleukodystrophy: deficiency of a specific acid esterase isozyme. Excerpt. Med. Intl. Cong. Ser. 397: 43 (1976).

8. Beaudet, A. L., Lipson, M. H., Ferry, G. D., and Nichols, B. L.: Acid lipase in cultured fibroblasts: cholesterol ester storage disease. J. Lab. Clin. Med., 84: 54 (1974).

9. Lowry, O. H., Rosebrough, N. J., Farr, A. L., et al: Protein measurement with folin phenol reagent. J. Biol. Chem., 193: 265 (1951).

10. Brecher, P., Pyun, H. Y., and Chobanian, A. V.: Effect of atherosclerosis on lysosomal cholesterol esterase activity in rabbit aorta. J. Lipid Res., 18: 154 (1977).

11. Ogino, T., Schaumburg, H. H., Suzuki, K., et al: Metabolic studies of adrenoleukodystrophy. In: J. Palo: Myelination and Demyelination. (New York, Plenum Press, 1978) p. 601.

12. This research was supported by National Institutes of Health grant GM-25397.

13. Requests for reprints should be addressed to: V. V. Michels, Department of Pediatrics, Baylor College of Medicine, Houston, Texas, 77030.

14. Received for publication November 21, 1978.

15. Accepted for publication January 30, 1979. 